\title{
Badanie oleju napędowego zawierającego 10\% (V/V) FAME i pakiet cetanowy w zakresie stabilności termooksydacyjnej
}

\author{
Testing of diesel oil containing 10\% (V/V) FAME and cetane package in terms of thermo- \\ oxidative stability
}

\author{
Winicjusz Stanik, Tomasz Łaczek \\ Instytut Nafty i Gazu - Państwowy Instytut Badawczy
}

\begin{abstract}
STRESZCZENIE: W artykule na podstawie wyników testów i badań przedstawiono wpływ nowego dodatku cetanowo-detergentowego Energocet ${ }^{\circledR}$ na stabilność oksydacyjną i podatność na utlenianie uszlachetnionych olejów napędowych B10 według metody PN-EN 15751:2010 (Rancimat) i PN-EN 16091:2011 (PetroOXY). Przed przystąpieniem do prac przeprowadzono przegląd literatury dla rozeznania tego tematu. Przechodząc do realizacji badań, postawiono cele do osiągnięcia, którymi były skomponowanie nowoczesnego pakietu cetanowo-detergentowego o nazwie Energocet ${ }^{\circledR}$ i pokazanie oddziaływania tego dodatku cetanowego na stabilność termooksydacyjną skomponowanych olejów typu B10 na podstawie wyników badań liczby nadtlenowej oraz stabilności skomponowanych paliw. Badania wykonano w oparciu o surowce, produkty i komponenty dostępne na polskim rynku paliw i biopaliw. Dla sprawdzenia skuteczności i wpływu nowego pakietu dodatków Energocet ${ }^{\circledR}$ na jakość komponowanych paliw w badaniach wykorzystano jeden typowy bazowy olej napędowy oraz dwa komponenty FAME różnych producentów. W badaniach do przygotowania bazowych paliw badawczych B10 użyto jednego bazowego oleju napędowego A oraz dwóch rodzajów estrów metylowych kwasów thuszczowych oleju rzepakowego (RME), oznaczonych jako B i C. Praca miała charakter technologiczno-analityczny. Na podstawie uzyskanych wyników badań dodatku cetanowo-detergentowego Energocet ${ }^{\circledR}$ w olejach napędowych zawierających FAME w ilości 10\% (V/V) (B10) oznaczono ich stabilność termooksydacyjną po trzech i sześciu tygodniach przechowywania w warunkach testów. Dodatkowo wyznaczono optymalny poziom dozowania pakietu cetanowo-detergentowego Energocet ${ }^{\circledR}$ w ilości $1500 \mathrm{mg} / \mathrm{kg} \mathrm{w}$ olejach napędowych B10 z udziałem RME-B i RME-C. Przedstawiono również skłonność uszlachetnionych badanych paliw do generowania wolnych rodników w czasie sześciotygodniowego przechowywania próbek w temperaturze $43^{\circ} \mathrm{C}$, oznaczonych w postaci liczby nadtlenkowej. Otrzymane wyniki potwierdziły, że dodatek cetanowo-detergentowy Energocet ${ }^{\circledR}$ korzystnie oddziałuje na parametry jakościowe paliw typu B10, w tym również na stabilność termooksydacyjną.
\end{abstract}

Słowa kluczowe: stabilność termooksydacyjna, pakiet dodatków uszlachetniających, estry metylowe wyższych kwasów thuszczowych (FAME), inhibitory utleniania, podatność na utlenianie.

ABSTRACT: Based on the results of tests and studies, the article presents the effect of the new Energocet ${ }^{\circledR}$ cetane-detergent additive on the oxidation stability and susceptibility to oxidation of B10 refined diesel oils according to the Rancimat PN-EN 15751: 2010 and PetroOXY PN 16091: 2011 method. Before starting the work, a literature review was carried out in terms of understanding this topic. Moving on to the research, the goals to be achieved were to compose a modern cetane-detergent package called Energocet ${ }^{\mathbb{Q}}$ and show the effect of this cetane additive on the thermo-oxidative stability of the B10 type oils based on the results of the research on the peroxygen number and stability of the composed fuels. The research was carried out on the basis of raw materials, products and components available on the Polish fuel and biofuel market. In order to check the effectiveness and impact of the new Energocet ${ }^{\circledR}$ additive package on the quality of the composed fuels, one typical base diesel oil and two FAME components from different manufacturers were used in the research. In the research, for the preparation of the B10 base research fuels, one base A diesel oil and 2 types of methyl esters of rapeseed oil fatty acids (RME) marked as B and C were used. The work was of technological and analytical nature. Based on the results

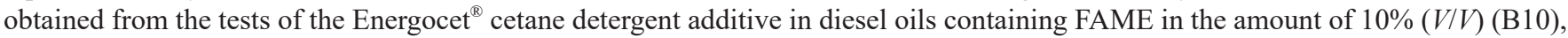
their thermo-oxidative stability was determined after three and six weeks of storage under test conditions. Additionally, the optimal dosing level of the Energocet ${ }^{\mathbb{Q}}$ cetane-detergent package in the amount of $1500 \mathrm{mg} / \mathrm{kg}$ in B10 diesel oils with RME-B and RME-C was determined. The tendency of the improved tested fuels to generate free radicals during the six-week storage of samples at the tempera-

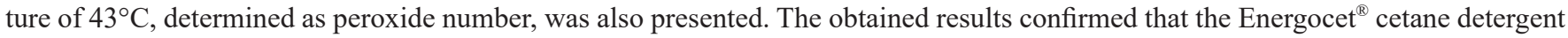
additive has a positive effect on the quality parameters of B10 fuels, including thermo-oxidative stability.

Key words: thermo-oxidative stability, package of improvers, methyl esters of higher fatty acids (FAME), oxidation inhibitors, susceptibility to oxidation.

Autor do korespondencji: T. Łaczek, e-mail: tomasz.laczek@inig.pl

Artykuł nadesłano do Redakcji: 26.08.2020 r. Zatwierdzono do druku: 07.12.2020 r. 


\section{Wstęp}

Światowa Karta Paliw (wydanie szóste z 2019 r.) zaleca, by olej napędowy kategorii 4 i 5 zawierający FAME i/lub inne biokomponenty typu HVO (ang. hydrotreated vegetable oil) uwodornionych olejów roślinnych lub BTL (ang. biomass to liquid) ciekłych paliw z biomasy miały liczbę cetanową minimum 55 jednostek (WWFC, 2019). Znany jest również ze Światowej Karty Paliw (WWFC, 2019) korzystny wpływ liczby cetanowej na rozruch silnika w niskiej temperaturze, jak również na emisję cząstek stałych (PM), tlenku węgla (CO), tlenków azotu $\left(\mathrm{NO}_{\mathrm{x}}\right)$ i niespalanych węglowodorów $(\mathrm{HC})$ (Ladommatos et al., 1996; Yannwang et al., 2002; Cataluna i da Silva, 2012; Stanik, 2017; WWFC, 2019).

Zwiększenie liczby cetanowej oleju napędowego ma znaczący wpływ na (Stanik, 2017):

- właściwości zapłonowe;

- przebieg procesu spalania;

- osiągi silnika;

- emisję tlenków azotu $\mathrm{NO}_{\mathrm{x}}$;

- emisję tlenku węgla $\mathrm{CO}$;

- emisję cząstek stałych PM;

- emisję niespalonych węglowodorów HC,

a ponadto wpływa na zmniejszenie zużycia paliwa, szczególnie w przypadku silników Diesla pracujących ze stosunkowo niewielkim obciążeniem, a więc w samochodach osobowych i lekkich pojazdach dostawczych (WWFC, 2019). Wyższa liczba cetanowa oleju napędowego umożliwia kontrolę opóźnienia zapłonu i stabilny przebieg spalania, szczególnie w nowoczesnych silnikach wysokoprężnych wyposażonych w wysokociśnieniowe układy wtrysku paliwa HPCRS (ang. high-pressure common rail system) i recyrkulację spalin. Olej napędowy o wyższej liczbie cetanowej poprawia właściwości rozruchowe silnika w niskiej temperaturze, zmniejszając cykl rozruchowy silnika. Liczba cetanowa jest miarą charakteryzującą zdolności oleju napędowego do samozapłonu w silniku o zapłonie samoczynnym i polega na pomiarze czasu opóźnienia samozapłonu, liczonego pomiędzy początkiem wtrysku paliwa a początkiem spalania wybuchowego, który powoduje wyraźny wzrost ciśnienia (Heywood, 1988). Okres opóźnienia samozapłonu może być wyrażony w milisekundach lub poprzez wartość kąta obrotu wału korbowego silnika przed górnym martwym położeniem tłoka (Owen et al., 1990).

Chemia i czas opóźnienia samozapłonu zależą od struktury molekularnej oleju napędowego oraz od kinetyki reakcji elementarnych niskotemperaturowego utleniania węglowodorów.

Proces opóźnienia samozapłonu chemicznego jest ciągle przedmiotem badań podstawowych polegających na modelowaniu kinetyki zaawansowanych reakcji chemicznych, bowiem cały proces utleniania niskotemperaturowego, przejściowego i wysokotemperaturowego jest bardzo złożony.

Samozapłon oleju napędowego występuje, gdy energia uwalniana poprzez wolnorodnikowe reakcje łańcuchowe wytwarza wykładniczy wzrost temperatury ładunku w cylindrze. Proces samozapłonu oleju napędowego jest inicjowany startem reakcji, które następnie generują wolne rodniki powstające ze stabilnych związków węglowodorowych.

Postęp rozgałęzionych reakcji łańcuchowych zwiększa liczbę wolnych rodników biorących udział w samozapłonie. Teoria reakcji łańcuchowej została opracowana i opublikowana przez Nikołaja Siemionowa, za którą otrzymał on wspólnie z Cyrilem Hinshelwoodem Nagrodę Nobla w dziedzinie chemii w roku 1956 (Siemionow, 1956).

W nowoczesnych silnikach o zapłonie samoczynnym, wyposażonych w układ wtryskowy common rail, olej napędowy, zanim trafi do komory spalania, ulega wielokrotnej recyrkulacji pomiędzy wtryskiwaczem a zbiornikiem paliwowym. Paliwo krążące w układzie paliwowym w zależności od wielkości zbiornika paliwowego i warunków pracy silnika może być narażone na wysokie ciśnienie i temperaturę powyżej $150^{\circ} \mathrm{C}$. Proces cyrkulacji niespalonego paliwa zachodzi w ograniczonym stopniu i wpływa na stabilność termooksydacyjną paliwa (Fang et al., 2003; Ulmann i Geduldig, 2009). Nowe dodatki cetanowo-detergentowe stosowane do uszlachetniania paliw do silników wysokoprężnych mają przeciwdziałać starzeniu paliwa i jednocześnie pozytywnie wpływać na inne parametry jakościowe paliwa. Przeprowadzony przegląd literaturowy (Stanik i Łaczek, 2020) i pozyskane dane potwierdziły, że dotychczas nie były prowadzone badania przedstawiające wpływ lub oddziaływanie tego rodzaju pakietu na stabilność termooksydacyjną i podatność na utlenianie olejów napędowych zawierających 10\% (V/V) FAME.

\section{Badanie olejów napędowych B10 zawierających pakiet Energocet ${ }^{\circledR}$}

Badania obejmowały wykonanie testów i oznaczeń w laboratorium metodami akredytowanymi w Instytucie Nafty i Gazu - Państwowym Instytucie Badawczym.

Badania podzielono na trzy etapy. W pierwszej części pracy przygotowano bazowy olej napędowy oraz estry metylowe wyższych kwasów tłuszczowych, które następnie gruntownie przebadano. Otrzymane wyniki wykorzystano do przygotowania nowego rodzaju cetanowo-detergentowego pakietu dodatków o nazwie Energocet ${ }^{\circledR}$, użytego następnie w dalszych badaniach do uszlachetniania próbek olejów napędowych B10.

W kolejnym etapie bazowe i uszlachetnione próbki paliw (B10) przygotowano do badań stabilnościowych. Ponieważ 
dotychczas nie opracowano metody badań przechowywania oleju napędowego z udziałem FAME i nie był ustalony okres jego przechowywania w określonych warunkach (dla oleju napędowego określa się go na 4 do 16 tygodni), stąd w celu wyznaczenia właściwości stabilności termooksydacyjnej oraz podatności tego rodzaju paliw na utlenianie skrócono okres magazynowania próbek do 4-6 tygodni, kontrolując liczbę nadtlenkową oraz prowadząc pomiary czasu indukcji metodą EN 15751 (Rancimat ${ }^{\circledR}$ ) i metodą EN 16091 (PetroOXY). Stabilność uszlachetnionego pakietem Energocet ${ }^{\circledR}$ oleju napędowego B10 zawierającego RME od producenta B oraz oleju napędowego B10 zawierającego RME od producenta $\mathrm{C}$ w ilości po $400 \mathrm{ml}$ badano, przechowując próbki w odpowiednich warunkach (w suszarce w temperaturze $43^{\circ} \mathrm{C}$ przez okres 6 tygodni) według metodyki opisanej w normie ASTM D4625 Standard Test Method for Middle Distillate Fuel Storage Stability at $43^{\circ} \mathrm{C}\left(110^{\circ} \mathrm{F}\right)$.

Końcowy etap to zebranie i przedstawienie uzyskanych wyników stabilności termooksydacyjnej uszlachetnionych próbek olejów napędowego B10 metodą Rancimat ${ }^{\circledR}$ i PetroOXY oraz wyników liczby nadtlenkowej, które posłużyły do sformułowania wniosków z badań i wykonania końcowej analizy wpływu pakietu Energocet ${ }^{\circledR}$ na odporność termooksydacyjną i podatność na utlenianie olejów napędowych typu B10.

Zakres badań obejmował przebadanie wpływu pakietu cetanowo-detergentowego Energocet ${ }^{\circledR}$ na wybrane właściwości olejów napędowych B10 o liczbie cetanowej 55 (a w szczególności jego wpływu na stabilność termooksydacyjną badanych paliw).

Pakiet Energocet ${ }^{\circledR}$ jest mieszaniną dodatku podwyższającego liczbę cetanową, inhibitorów utleniania oraz dodatku detergentowo-dyspergującego w odpowiednich proporcjach.

\section{Wyniki badań}

W tabeli 1 przedstawiono właściwości fizykochemiczne i użytkowe bazowego oleju napędowego A zastosowanego w badaniach.

W tabeli 2 przedstawiono właściwości fizykochemiczne i użytkowe estrów metylowych kwasów oleju rzepakowego (RME) B i C.

W tabeli 3 przedstawiono właściwości fizykochemiczne i użytkowe dla oleju napędowego B10 z udziałem estrów metylowych wyższych kwasów thuszczowych B oraz C.

Tabela 1. Właściwości fizykochemiczne i użytkowe bazowego oleju napędowego A

Table 1. Physicochemical and functional properties of A base diesel fuel

\begin{tabular}{|c|c|c|c|}
\hline Wlaściwość & Metoda & Jednostka & Wyniki \\
\hline Liczba cetanowa & PN-EN ISO 5165:2003 & - & $52,9 \pm 3,3$ \\
\hline Pochodna liczby cetanowej & PN-EN 16715:2015 & - & $54,01 \pm 0,12$ \\
\hline Indeks cetanowy & PN-EN ISO 4264:2010 + A1:2013-07 & - & $54,6 \pm 0,8$ \\
\hline Gęstość w temperaturze $15^{\circ} \mathrm{C}$ & PN-EN ISO 12185:2002 & $\mathrm{kg} / \mathrm{m}^{3}$ & $824,8 \pm 0,4$ \\
\hline Zawartość wielopierścieniowych węglowodorów aromatycznych & PN-EN 12916:2016-03 & $\%(m / m)$ & $<1,0$ \\
\hline Zawartość siarki & PN-EN ISO 20846:2012 & $\mathrm{mg} / \mathrm{kg}$ & $5,4 \pm 1,2$ \\
\hline Zawartość manganu & PN-EN 16576:2014-12/Ap1:2017-11 & $\mathrm{mg} / \mathrm{l}$ & $<0,5$ \\
\hline Temperatura zapłonu & PN-EN ISO 3679:2015 & ${ }^{\circ} \mathrm{C}$ & $58,5 \pm 2,5$ \\
\hline Pozostałość po koksowaniu (z 10\% pozostałości destylacyjnej) & PN-EN ISO 10370:2014-12 & $\%(m / m)$ & $0,008 \pm 0,01$ \\
\hline Zawartość wody & PN-EN ISO 12937:2005 & $\mathrm{mg} / \mathrm{kg}$ & $33 \pm 28$ \\
\hline Zawartość zanieczyszczeń stałych & PN-EN 12662:2009 & $\mathrm{mg} / \mathrm{kg}$ & $6,8 \pm 3,7$ \\
\hline Badanie działania korodującego na miedź $\left(3 \mathrm{~h}, 50^{\circ} \mathrm{C}\right)$ & PN-EN ISO 2160:2004 & stopień korozji & 1 \\
\hline Stabilność oksydacyjna & PN-ISO 12205:2011 + Ap1:2011 & $\mathrm{g} / \mathrm{m}^{3}$ & $9 \pm 7$ \\
\hline Smarność, skorygowana średnica śladu zużycia, w temp $60^{\circ} \mathrm{C}$ & PN-EN ISO 12156-1:2008 & $\mu \mathrm{m}$ & $400 \pm 73$ \\
\hline Lepkość kinematyczna w temperaturze $40^{\circ} \mathrm{C}$ & PN-EN ISO 3104:2004 & $\mathrm{mm}^{2} / \mathrm{s}$ & $2,602 \pm 0,022$ \\
\hline $\begin{array}{l}\text { Skład frakcyjny: } \\
\text { - do temp. } 250^{\circ} \mathrm{C} \text { destyluje } \\
\text { - do temp. } 350^{\circ} \mathrm{C} \text { destyluje } \\
\text { - } 95 \%(V / V) \text { destyluje do temp. }\end{array}$ & PN-EN ISO 3405:2012 & $\begin{array}{l}\%(V / V) \\
\%(V / V) \\
{ }^{\circ} \mathrm{C}\end{array}$ & $\begin{array}{c}42,1 \pm 1,9 \\
92,5 \pm 1,9 \\
358,3 \pm 6,6\end{array}$ \\
\hline Zawartość estrów metylowych kwasów tłuszczowych (FAME) & PN EN 14078:2014-06 & $\%(V / V)$ & $0,11 \pm 0,02$ \\
\hline Zawartość po spopieleniu & PN-EN ISO 6245:2008 & $\%(m / m)$ & $<0,001$ \\
\hline Skład granulometryczny zanieczyszczeń stałych & ISO 4406 & $\begin{array}{l}\text { oznaczenie } \\
\text { kodowe }\end{array}$ & $18 / 16 / 13$ \\
\hline
\end{tabular}


Tabela 2. Właściwości fizykochemiczne i użytkowe estrów metylowych kwasów oleju rzepakowego (RME) wykorzystanych w badaniach

Table 2. Physicochemical and functional properties of rapeseed oil acid methyl esters (RME) used in the tests

\begin{tabular}{|c|c|c|c|c|}
\hline \multirow{2}{*}{ Właściwość } & \multirow{2}{*}{ Metoda } & \multirow{2}{*}{ Jednostka } & \multicolumn{2}{|c|}{ Wyniki oznaczeń } \\
\hline & & & estry metylowe B & estry metylowe $\mathrm{C}$ \\
\hline $\begin{array}{l}\text { Zawartość estrów metylowych kwasów thuszczowych } \\
\text { (FAME) }\end{array}$ & PN-EN 14103:2012 & $\%(m / m)$ & 98,8 & 98,6 \\
\hline Zawartość estru metylowego kwasu linolenowego & PN-EN 14103:2012 & $\%(m / m)$ & 8,5 & 8,3 \\
\hline Gęstość w temperaturze $15^{\circ} \mathrm{C}$ & PN-EN ISO 12185:2002 & $\mathrm{kg} / \mathrm{m}^{3}$ & 882,8 & 882,7 \\
\hline Lepkość kinematyczna w temperaturze $40^{\circ} \mathrm{C}$ & PN-EN ISO 3104:2004 & $\mathrm{mm}^{2} / \mathrm{s}$ & 4,500 & 4,49 \\
\hline Temperatura zapłonu & PN-EN ISO 3679:2015 & ${ }^{\circ} \mathrm{C}$ & 176,5 & $>101$ \\
\hline Zawartość siarki & PN-EN ISO 20846:2012 & $\mathrm{mg} / \mathrm{kg}$ & $<3$ & $<3$ \\
\hline Liczba cetanowa & PN-EN ISO 5165:2003 & - & 51,5 & 52,0 \\
\hline Pochodna liczby cetanowej & PN-EN 16715:2015 & - & 51,0 & - \\
\hline Zawartość popiołu siarczanowego & PN-ISO 3987:2014 & $\%(m / m)$ & $<0,005$ & $<0,005$ \\
\hline Zawartość wody & PN-EN ISO 12937:2005 & $\mathrm{mg} / \mathrm{kg}$ & 151 & 105 \\
\hline Zawartość zanieczyszczeń stałych & PN-EN 12662:2009 & $\mathrm{mg} / \mathrm{kg}$ & 8,6 & 4,0 \\
\hline Badanie działania korodującego na miedź $\left(3 \mathrm{~h}, 50^{\circ} \mathrm{C}\right)$ & PN-EN ISO 2160:2004 & stopień korozji & 1 & 1 \\
\hline $\begin{array}{l}\text { Stabilność oksydacyjna w temperaturze } 110^{\circ} \mathrm{C} \\
\text { (Rancimat) }\end{array}$ & PN-EN 15751:2014 & $\mathrm{h}$ & 10,4 & 11,2 \\
\hline Liczba kwasowa & PN-EN 14104:2004 & $\mathrm{mg} \mathrm{KOH} / \mathrm{g}$ & 0,26 & 0,30 \\
\hline Liczba jodowa & PN-EN 14111:2004 & $\mathrm{g}$ jodu/100 g & 109,2 & 106 \\
\hline $\begin{array}{l}\text { Zawartość estrów metylowych kwasów polienowych } \\
\text { (zawierających nie mniej niż cztery wiązania podwójne) }\end{array}$ & PN-EN 15777:2013 & $\%(m / m)$ & $<0,6$ & $<0,6$ \\
\hline Zawartość alkoholu metylowego & PN-EN 14110 & $\%(m / m)$ & 0,03 & $<0,05$ \\
\hline Zawartość monoacylogliceroli & PN-EN 14105:2012 & $\%(m / m)$ & 0,67 & 0,57 \\
\hline Zawartość diacylogliceroli & PN-EN 14105:2012 & $\%(m / m)$ & $<0,10$ & 0,14 \\
\hline Zawartość triacylogliceroli & PN-EN 14105:2012 & $\%(m / m)$ & $<0,10$ & $<0,05$ \\
\hline Zawartość wolnego glicerolu & PN-EN 14105:2012 & $\%(m / m)$ & 0,007 & $<0,005$ \\
\hline Zawartość ogólnego glicerolu & PN-EN 14105:2012 & $\%(m / m)$ & $0,19 \pm 0,034$ & 0,17 \\
\hline Zawartość metali grupy I (Na + K) & PN EN 14538:2008 & $\mathrm{mg} / \mathrm{kg}$ & $<2,0$ & $<5,0$ \\
\hline Zawartość metali grupy II (Ca + Mg) & PN EN 14538:2008 & $\mathrm{mg} / \mathrm{kg}$ & $<2,0$ & $<5,0$ \\
\hline Zawartość fosforu & PN-EN 14107:2004 & $\mathrm{mg} / \mathrm{kg}$ & $<4,0$ & $<4,0$ \\
\hline
\end{tabular}

Europejska dyrektywa w sprawie odnawialnych źródeł energii zobowiązuje do tego, aby $10 \%$ energii wykorzystywanej w transporcie uzyskać ze źródeł odnawialnych do $2020 \mathrm{r}$. (RED - Renewable Energy Directive, 2009/28/WE). W tym kontekście paliwa transportowe są definiowane jako benzyna, olej napędowy i biopaliwa dla transportu drogowego i kolejowego, jak również energia elektryczna do zasilania pojazdów elektrycznych. Ten mandat na paliwa transportowe dotyczy nie tylko stosowania biopaliw takich jak estry metylowe kwasów tłuszczowych (FAME) i bioetanol, ale także odnawialnej energii elektrycznej i wodoru ze źródeł odnawialnych. Równolegle Europejska dyrektywa w sprawie jakości paliwa (FQD - Fuel Quality Directive, 2009/30/WE) wymaga 6-procentowej redukcji emisji gazów cieplarnianych (GHG) z paliw transportowych do 2020 roku w porównaniu do linii bazowej z 2010 roku. Cel ten może zostać osiągnięty poprzez mieszanie w sposób zrównoważony produkowanych biopaliw ciekłych z paliwami pochodzenia naftowego o korzystnym wpływie na GHG. Oba cele muszą zostać spełnione.

Aktualna norma PN-EN 590 dotyczy oleju napędowego B7 o zawartości FAME do 7\% $(V / V)$. Mieszanki FAME o stężeniu do 10\% (V/V) dopuszczone normą PN-EN 16734 mogą umożliwić producentom oleju napędowego osiągnięcie celów dyrektyw RED i FQD. Zwiększenie zawartości FAME w oleju napędowym powoduje problemy z dotrzymaniem wielu parametrów jakościowych zawartych w normie (PN-EN 590:2017). Jednym z parametrów wpływającym na jakość oleju napędowego B10 jest stabilność oksydacyjna. Wymagania dotyczące stabilności oksydacyjnej zostały zawarte: w normie PN-EN 14214 dla samoistnego paliwa B100 i oleju napędowego B7 zawierającego więcej niż 2\% $(V / V)$ i nie mniej niż 7\% $(V / V)$ FAME oraz w normie PN-EN 590 i w normie PN-EN 16734 
Tabela 3. Właściwości fizykochemiczne i użytkowe oleju napędowego B10 z udziałem estrów metylowych wyższych kwasów tłuszczowych B oraz C

Table 3. Physicochemical and functional properties of B10 diesel fuel with the participation of methyl esters of higher fatty acids B and C

\begin{tabular}{|c|c|c|c|c|}
\hline \multirow[b]{2}{*}{ Wlaściwość } & \multirow[b]{2}{*}{ Metoda } & \multirow[b]{2}{*}{ Jednostka } & \multicolumn{2}{|c|}{ Wyniki } \\
\hline & & & $\begin{array}{l}\text { olej napędowy B10 } \\
\text { z estrami B }\end{array}$ & $\begin{array}{c}\text { olej napędowy B10 } \\
\text { z estrami C }\end{array}$ \\
\hline Liczba cetanowa & PN-EN ISO 5165:2003 & - & $52,3 \pm 3,0$ & $52,5 \pm 3,0$ \\
\hline Indeks cetanowy & $\begin{array}{l}\text { PN-EN ISO 4264:2010+ } \\
\text { A1:2013-07 }\end{array}$ & - & $55,0 \pm 0,8$ & $55,4 \pm 0,8$ \\
\hline Gęstość w temperaturze $15^{\circ} \mathrm{C}$ & PN-EN ISO 12185:2002 & $\mathrm{kg} / \mathrm{m}^{3}$ & $830,4 \pm 0,4$ & $830,6 \pm 0,4$ \\
\hline $\begin{array}{l}\text { Zawartość wielopierścieniowych węglowodo- } \\
\text { rów aromatycznych }\end{array}$ & PN-EN 12916:2016-03 & $\%(m / m)$ & $1,1 \pm 0,5$ & $\pm 0,4$ \\
\hline Zawartość siarki & PN-EN ISO 20846:2012 & $\mathrm{mg} / \mathrm{kg}$ & $4,9 \pm 1,2$ & $4,5 \pm 1,2$ \\
\hline Zawartość manganu & $\begin{array}{l}\text { PN-EN 16576:2014-12/ } \\
\text { Ap1:2017-11 }\end{array}$ & $\mathrm{mg} / 1$ & $<0,5$ & - \\
\hline Temperatura zapłonu & PN-EN ISO 3679:2015 & ${ }^{\circ} \mathrm{C}$ & $60,5 \pm 2,5$ & $61,5 \pm 2,5$ \\
\hline $\begin{array}{l}\text { Pozostałość po koksowaniu (z 10\% pozostałości } \\
\text { destylacyjnej) }\end{array}$ & PN-EN ISO 10370:2014-12 & $\%(m / m)$ & $0,016 \pm 0,012$ & $0,10 \pm 0,04$ \\
\hline Zawartość wody & PN-EN ISO 12937:2005 & $\mathrm{mg} / \mathrm{kg}$ & $60 \pm 38$ & $<30,0$ \\
\hline Zawartość zanieczyszczeń stałych & PN-EN 12662:2009 & $\mathrm{mg} / \mathrm{kg}$ & $20,5 \pm 5,4$ & - \\
\hline $\begin{array}{l}\text { Badanie działania korodującego na miedź ( } 3 \mathrm{~h} \text {, } \\
\left.50^{\circ} \mathrm{C}\right)\end{array}$ & PN-EN ISO 2160:2004 & stopień korozji & 1 & - \\
\hline Stabilność oksydacyjna & $\begin{array}{c}\text { PN-ISO 12205:2011+ } \\
\text { Ap1:2011 }\end{array}$ & $\mathrm{g} / \mathrm{m}^{3}$ & $8 \pm 7$ & - \\
\hline $\begin{array}{l}\text { Stabilność oksydacyjna w temperaturze } 110^{\circ} \mathrm{C} \\
\text { (Rancimat) }\end{array}$ & PN-EN 15751:2014 & $\mathrm{h}$ & 23,1 & - \\
\hline $\begin{array}{l}\text { Smarność, skorygowana średnica śladu zużycia, } \\
\text { w temp } 60^{\circ} \mathrm{C}\end{array}$ & PN-EN ISO 12156-1:2008 & $\mu \mathrm{m}$ & $165 \pm 73$ & - \\
\hline Lepkość kinematyczna w temperaturze $40^{\circ} \mathrm{C}$ & PN-EN ISO 3104:2004 & $\mathrm{mm}^{2} / \mathrm{s}$ & $2,730 \pm 0,022$ & $2,710 \pm 0,015$ \\
\hline $\begin{array}{l}\text { Skład frakcyjny } \\
\text { - do temp. } 250^{\circ} \mathrm{C} \text { destyluje } \\
\text { - do temp. } 350^{\circ} \mathrm{C} \text { destyluje } \\
-95 \%(V / V) \text { destyluje do temp. }\end{array}$ & PN-EN ISO 3405:2012 & $\begin{array}{l}\%(V / V) \\
\%(V / V) \\
\quad{ }^{\circ} \mathrm{C}\end{array}$ & $\begin{array}{c}36,8 \pm 1,9 \\
93 \pm 1,9 \\
355,9 \pm 6,6\end{array}$ & $\begin{array}{c}36,5 \pm 1,9 \\
93,1 \pm 1,9 \\
354,8 \pm 6,6\end{array}$ \\
\hline $\begin{array}{l}\text { Zawartość estrów metylowych kwasów thusz- } \\
\text { czowych (FAME) }\end{array}$ & PN EN 14078:2014-06 & $\%(V / V)$ & $9,9 \pm 0,5$ & $9,7 \pm 0,5$ \\
\hline Zawartość po spopieleniu & PN-EN ISO 6245:2008 & $\%(m / m)$ & $<0,001$ & - \\
\hline
\end{tabular}

dla oleju B10 zawierającego maksymalnie 10\% (V/V) FAME. W wyżej wymienionych normach zaleca się dozowanie inhibitorów utleniania zwiększających stabilność oksydacyjną FAME w procesie produkcyjnym, aby chronić FAME przed utlenianiem $\mathrm{i} /$ lub degradacją w czasie mieszania z olejem napędowym pochodzenia naftowego. Stabilność oksydacyjna oleju napędowego zawierającego FAME jest niższa niż oleju napędowego B0 niezawierającego FAME.

Standardowy test przyśpieszonego utleniania nazywany metodą Rancimat został przyjęty w normach EN 14112 i ASTM D 6751 na estry metylowe kwasów tłuszczowych (FAME).

Wymagania odporności na utlenianie wynoszą odpowiednio według norm EN 15751 i EN ISO 12205:

- FAME (B100) - minimum 8 godzin;
- B7 - minimum 20 godzin i maks. $25 \mathrm{~g} / \mathrm{m}^{3}$ całkowitych osadów nierozpuszczalnych;

- B10 - minimum 20 godzin i maks. $25 \mathrm{~g} / \mathrm{m}^{3}$ całkowitych osadów nierozpuszczalnych.

Stabilność przechowywania ciekłego paliwa jest określana przez zdolność zapobiegania fizycznym i chemicznym zmianom spowodowanym przez interakcję $z$ otoczeniem.

Olej napędowy zawierający FAME ulega degradacji w czasie magazynowania w różnym stopniu, zależnym od wielu czynników, w następujący sposób:

- w kontakcie z tlenem z powietrza ulega procesom utleniania i autooksydacji;

- w wyższych temperaturach ulega rozkładowi termicznemu i termooksydacyjnemu; 
- w kontakcie z wodą i wilgocią w czasie magazynowania i transportu ulega hydrolizie i odwrotnej transestryfikacji;

- w przypadku nienależytego utrzymania zbiorników w czystości ulega zakażeniu mikrobiologicznemu.

Adaptacja istniejącej metody badań stabilności oksydacyjnej średnich destylatów paliwowych EN ISO 12205 eliminuje ją jako metodę do monitorowania lub kontroli punktowej stabilności oleju napędowego B10 podczas jego przechowywania $\mathrm{w}$ dowolnym przedziale czasu. W metodzie tej próbka analityczna przesączonego oleju napędowego jest poddawana procesowi starzenia w temperaturze $95^{\circ} \mathrm{C}$ przez 16 godzin przy przepływie tlenu przez próbkę $3,0 \mathrm{l} / \mathrm{h} \pm 0,3 \mathrm{l} / \mathrm{h}$. Po procesie starzenia próbka jest schładzana do temperatury pokojowej, a następnie sączona w celu oznaczenia zawartości filtrowalnych osadów nierozpuszczalnych. Osady nierozpuszczalne przylegające są usuwane z zestawu do utleniania i innych szklanych części rozpuszczalnikiem trójskładnikowym. Rozpuszczalnik trójskładnikowy jest odparowywany w celu uzyskania osadów nierozpuszczalnych przylegających. Suma osadów nierozpuszczalnych przylegających i osadów nierozpuszczalnych filtrowalnych jest podawana jako całkowite osady nierozpuszczalne. Ilość osadów nierozpuszczalnych powstających w czasie takiego przechowywania zależy od specyficznych warunków, które są zbyt zmienne, aby ta metoda pozwoliła na ich dokładne określenie, $\mathrm{z}$ powodu tworzenia trudnych do wyodrębnienia rozpuszczalnych polimerów pochodzących z utleniania estrów metylowych kwasów tłuszczowych (Dunn, 2008).

Dotychczas nie opracowano metody badań przechowywania oleju napędowego z udziałem FAME. Metoda badań oleju napędowego według ASTM D4625 zalecana jest w stosunku do paliw destylatowych o temperaturze zapłonu $38^{\circ} \mathrm{C}$ i temperaturze destylacji $90 \%(V / V)$ poniżej $340^{\circ} \mathrm{C}$. Warunki przechowywania w przypadku tej metody są następujące: $400 \mathrm{ml}$ próbki umieszcza się w 500-mililitrowej szklanej butelce, pokrywka pojemnika na próbkę jest wentylowana szklaną rurką, aby umożliwić parowanie. Próbki przechowywane są w suszarce w temperaturze $43^{\circ} \mathrm{C}$ w celu przyśpieszenia starzenia i testowane w regularnych odstępach czasu. Metoda uwzględnia jeden tydzień przechowywania w tych warunkach odpowiadający jednemu miesiącowi rzeczywistego podziemnego składowania dla oleju napędowego niezawierającego FAME w temperaturze $21^{\circ} \mathrm{C}$.

W stosunku do oleju napędowego zawierającego FAME nie ustalono okresu przechowywania w tych warunkach, który to okres dla oleju napędowego określa się na 4 do 16 tygodni (McCormick i Westbrook, 2010).

W celu zbadania czasu przechowywania oleju napędowego zawierającego FAME skrócono okres przechowywania próbek do od 4 do 6 tygodni, mierząc liczbę nadtlenkową oraz czas indukcji metodą EN 15751 (Rancimat $^{\circledR}$ ) i metodą EN 16091 (PetroOXY).

Ogólnie olej napędowy B10, zawierający zwiększoną zawartość FAME, jest stabilny przy braku dostępu tlenu, wody i światła. Jednak podwyższona temperatura przechowywania i przedłużony czas przechowywania mogą zwiększyć tempo procesów degradacji paliwa. Istotną przyczyną jest stabilność oksydacyjna, zależna od jakości FAME oraz zawartości związków nienasyconych, mających istotny wpływ na degradację paliwa, tworzenie osadów i zatykanie filtrów paliwowych.

Według normy PN-EN 14214 + A1:2014 stabilność oksydacyjna FAME w temperaturze $110^{\circ} \mathrm{C}$ oznaczona według normy PN-EN 15751 wynosi minimum 8 godzin.

Zawartość związków nienasyconych wynosi natomiast odpowiednio:

- liczba jodowa - maksymalnie 120 g jodu/100 g;

- zawartość estru metylowego kwasu linolenowego - maksymalnie $12 \%(\mathrm{~m} / \mathrm{m})$;

- zawartość estrów metylowych kwasów polienowych zawierających nie mniej niż cztery podwójne wiązania - maksymalnie $1,0 \%(\mathrm{~m} / \mathrm{m})$.

W tabeli 4 przedstawiono wyniki badań stabilności oksydacyjnej, liczby jodowej, zawartości estru metylowego kwasu linolenowego oraz estrów metylowych kwasów polienowych zawierających nie mniej niż cztery podwójne wiązania dla estrów metylowych kwasów tłuszczowych oleju rzepakowego produkcji B i C.

Próbki oleju napędowego B10 zawierającego estry B oraz oleju napędowego B10 zawierającego estry $\mathrm{C}$ w ilości

Tabela 4. Zawartość kwasów nienasyconych i stabilność oksydacyjna estrów metylowych kwasów oleju rzepakowego B oraz C

Table 4. Unsaturated acid content and oxidative stability of B and C rapeseed oil methyl esters

\begin{tabular}{|l|c|c|c|c|}
\hline \multicolumn{1}{|c|}{ Wlaściwość } & Jednostka & $\begin{array}{c}\text { Wymagania według } \\
\text { PN-EN 14214 }\end{array}$ & RME od producenta B & RME od producenta C \\
\hline \hline Stabilność oksydacyjna w temperaturze $110^{\circ} \mathrm{C}$ & $\mathrm{h}$ & $>8$ & 10,4 & 11,2 \\
\hline Liczba jodowa & $\mathrm{g}$ jodu/100 g & $<120$ & 109,2 & 106,0 \\
\hline Zawartość estru metylowego kwasu linolenowego & $\%(\mathrm{~m} / \mathrm{m})$ & $<12$ & 8,5 & 8,3 \\
\hline $\begin{array}{l}\text { Zawartość estrów metylowych kwasów polieno- } \\
\text { wych zawierających nie mniej niż cztery podwój- } \\
\text { ne wiązania }\end{array}$ & $\%(\mathrm{~m} / \mathrm{m})$ & 1,0 & $<0,6$ & $<0,6$ \\
\hline
\end{tabular}


po $400 \mathrm{ml}$ uszlachetniono $1500 \mathrm{mg} / \mathrm{kg}$ pakietu dodatków Energocet $^{\circledR}$, umieszczono w suszarce w temperaturze $43^{\circ} \mathrm{C}$ i badano przez 6 tygodni według metodyki opisanej w normie ASTM D4625. Dodatkowo próbki wyjściowe poddano badaniom stabilności oksydacyjnej według PN-EN 15751:2010.

W badaniu tym przez próbkę oleju napędowego wielkości $7,5 \mathrm{~g} \pm 0,1 \mathrm{~g}$ przepuszcza się strumień oczyszczonego powietrza przy przepływie $10 \mathrm{l} / \mathrm{h}$ w temperaturze $110^{\circ} \mathrm{C}$.

Wrażliwość oleju napędowego B10 wynika zarówno z ilości zastosowanego FAME, jak i jego struktury molekularnej, a przede wszystkim zależy od struktury i liczby wiązań podwójnych. Obecność konfiguracji bis-allilowych $(-\mathrm{CH}=\mathrm{CH}$ $-\mathrm{CH}_{2}-\mathrm{CH}=\mathrm{CH}-$ ) w strukturze molekularnej, gdzie centralna grupa metylenowa aktywowana jest przez dwa wiązania podwójne, powoduje, że cząsteczka posiada dużą niestabilność i ten rodzaj konfiguracji jest bardzo podatny na utlenianie, i prowadzi do reakcji polimeryzacji i wzrostu lepkości FAME. Tlen z powietrza łatwo przyłącza się do wiązań bis-allilowych i inicjuje sekwencję reakcji łańcuchowego utleniania. A zatem stabilność oksydacyjna zależy od liczby wiązań bis-allilowych w nienasyconych estrach. Na ogólną stabilność oksydacyjną wpływa również izomeryzacja konformacyjna wywołana wysokimi temperaturami wiązań podwójnych cis-trans. Izomeryzacja konformacyjna cis-trans wpływa na stabilność oksydacyjną różnych izomerów, co przedstawiono na rysunku 1 w kolejności malejącej stabilności.

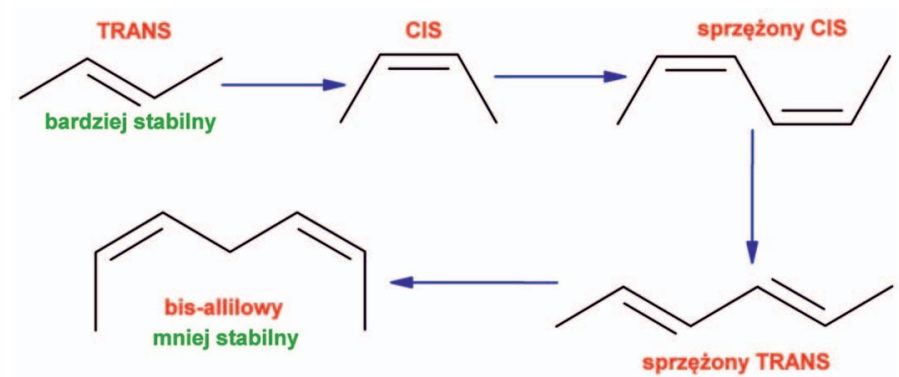

Rys. 1. Izomeryzacja konformacyjna cis-trans

Fig. 1. Cis - trans conformational isomerization

Lotne związki jako wtórne produkty utleniania, takie jak aldehydy, ketony, kwasy o niskiej masie cząsteczkowej, uwalniane z próbki w procesie utleniania, przechodzą wraz z powietrzem do naczynia pomiarowego zawierającego wodę demineralizowaną lub destylowaną, zaopatrzonego w elektrodę do pomiaru przewodności właściwej. Elektroda połączona jest z jednostką pomiarową i rejestrującą. Wskazuje ona koniec okresu indukcji w chwili, gdy przewodność właściwa zaczyna gwałtownie wzrastać. Przyspieszony wzrost jest spowodowany dysocjacją lotnych kwasów karboksylowych, które tworzą się w procesie utleniania i zostają zaabsorbowane w wodzie. Wyniki są rejestrowane w sposób graficzny pozwalający wyznaczyć okres indukcyjny (IP, ang. induction period) badanej próbki.

Wykonano również badania stabilności oksydacyjnej metodą PetroOXY według normy PN-EN 16091:2011 lub ASTM D7545:2014. Paliwa i mieszaniny ze średnich destylatów naftowych i estrów metylowych kwasów tłuszczowych (FAME) wykonuje się w temperaturze $140^{\circ} \mathrm{C}$ i pod ciśnieniem $700 \mathrm{kPa}$. Badanie określa stabilność oleju napędowego i symuluje warunki panujące w układzie wtryskowym paliwa, które chłodząc końcówkę iglicy wysokociśnieniowego wtryskiwacza, powraca przelewem z wtryskiwacza do zbiornika paliwowego. Paliwo to, wielokrotnie cyrkulując pomiędzy wtryskiwaczem a zbiornikiem paliwowym, jest narażane na temperaturową i oksydacyjną degradację.

Oznaczenie odporności na utlenianie według EN 16091:2011 metodą szybkiego utleniania w małej skali polega na tym, że próbkę oleju napędowego wielkości $5 \mathrm{ml}$ umieszcza się w ciśnieniowym naczyniu reakcyjnym, zwiększa się ciśnienie do $700 \pm 5 \mathrm{kPa}$ przy użyciu tlenu i ogrzewa próbkę do temperatury $140^{\circ} \mathrm{C}$. Warunki te inicjują szybki proces utleniania, który jest mierzony przez spadek ciśnienia w ciśnieniowym naczyniu reakcyjnym. Stosuje się dostępny na rynku tlen o czystości nie mniejszej niż 99,6\% i zawartości wody poniżej $5 \mathrm{mg} / \mathrm{kg}$. Okres indukcyjny, charakteryzujący odporność na utlenianie, oznaczany jest jako czas pomiędzy rozpoczęciem badania a punktem załamania, który określa się jako 10-procentowy spadek ciśnienia w stosunku do ciśnienia maksymalnego w funkcji czasu w temperaturze badania $140^{\circ} \mathrm{C} \pm 0,5^{\circ} \mathrm{C}$. Ciśnienie w naczyniu reakcyjnym jest rejestrowane w odstępach 2-sekundowych, aż do osiągnięcia punktu załamania. Na rysunku 2 przedstawiono profil ciśnienia podczas badania i wyznaczania okresu indukcji.

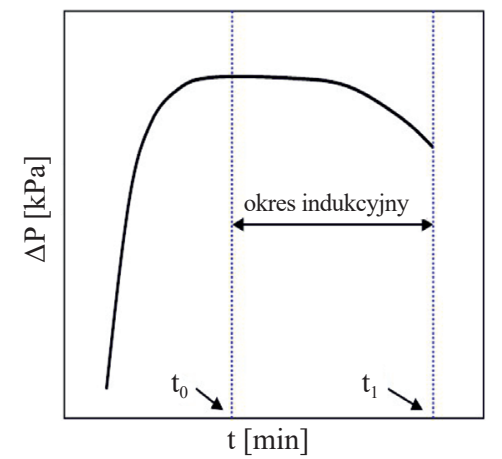

Rys. 2. Profil ciśnienia podczas badania i wyznaczania okresu indukcji; $\mathrm{t}_{0}$ - czas osiągnięcia maksymalnego ciśnienia, $\mathrm{t}_{1}$ - czas osiągnięcia 10-procentowego spadku ciśnienia

Fig. 2. Pressure profile during the test and determination of the induction period; $\mathrm{t}_{0}$ - time to reach the maximum pressure, $\mathrm{t}_{1}-$ time achieving a $10 \%$ pressure drop

Przed przystąpieniem do procesu starzenia oleju napędowego B10 oznaczono również liczbę nadtlenkową metodą PN-EN ISO 3960:2012. 
Przechowywane w temperaturze $43^{\circ} \mathrm{C}$ próbki badano po 3 tygodniach przechowywania oraz po 6 tygodniach przechowywania, oznaczając stabilność oksydacyjną metodą Rancimat ${ }^{\circledR}$ i metodą PetroOXY oraz oznaczając liczbę nadtlenkową. Po 6 tygodniach przechowywania próbek oleju napędowego B10 w temperaturze $43^{\circ} \mathrm{C}$, odpowiadającemu sześciomiesięcznemu magazynowaniu paliwa $\mathrm{w}$ zbiornikach podziemnych w temperaturze $21^{\circ} \mathrm{C}$, oznaczono całkowitą zawartość substancji nierozpuszczalnych, nazywanych zanieczyszczeniem, w średnich destylatach, olejach oraz estrach metylowych kwasów tłuszczowych według metody PN-EN 12662:2014.

Wyniki pomiarów stabilności oksydacyjnej metodą Rancimat ${ }^{\circledR}$ i PetroOXY oraz liczbę nadtlenkową zamieszczono w tabelach 5 i 6. Na rysunkach 3, 4 i 5 przedstawiono również wyniki stabilności oksydacyjnej i przyrostu liczby nadtlenkowej dla oleju napędowego B10 z udziałem RME-B oraz oleju napędowego B10 z udziałem RME-C.

W normie na olej napędowy zawierający do 7\% ( V/V) FAME (PN-EN 590 + A1:2017) i w normie PN-EN 16734:2016 ustalono limit stabilności oksydacyjnej według metody PN-EN 15751 na poziomie 20 godzin. W obu normach dla oleju napędowego B7 i B10 nie ustalono limitów okresu indukcyjnego mierzonego metodą PN-EN 16091:2011 (PetroOXY).

Limit całkowitych zanieczyszczeń w średnich destylatach, olejach napędowych oraz estrach metylowych kwasów tłuszczowych oznaczonych według normy PN-EN ISO 12662:2014 dla oleju napędowego B7 i B10 wynosi natomiast $25 \mathrm{mg} / \mathrm{kg}$.

Zgodnie z szóstą edycją Światowej Karty Paliw, z października 2019 roku, dla oleju napędowego kategorii pierwszej o zawartości siarki maksymalnie do $2000 \mathrm{mg} / \mathrm{kg}$ zawierającego 5\% $(V / V)$ FAME ustalono minimalny okres indukcyjny według metody Rancimat ${ }^{\circledR}$ na poziomie 30 godzin, a według metody PetroOXY - na poziomie 60 minut. Dla olejów kategorii 2, 3 i 4 o zawartości siarki odpowiednio
$300 \mathrm{mg} / \mathrm{kg}, 50 \mathrm{mg} / \mathrm{kg}$ i $10 \mathrm{mg} / \mathrm{kg}$ zawierających 5\% (V/V) FAME okres indukcyjny według metody Rancimat ${ }^{\circledR}$ wynosi minimum 35 godzin, a w przypadku metody PetroOXY - minimum 65 minut.

Tak jak wcześniej podano, w przypadku olejów napędowych B7 i B10 o liczbie cetanowej 55 w Światowej Karcie Paliw (WWFC, 2019) nie ustalono limitów dla okresu indukcyjnego.

Tabela 5. Wyniki badań w czasie przechowywania oleju napędowego B10 z udziałem RME produkcji B

Table 5. Test results during storage of B10 diesel fuel with the participation of RME of B production

\begin{tabular}{|l|c|c|c|c|}
\hline \multicolumn{5}{|c|}{ Olej napędowy B10 (RME-B) } \\
\hline \multirow{2}{*}{ Wlaściwość } & \multirow{2}{*}{ Jednostka } & \multicolumn{3}{c|}{$\begin{array}{c}\text { Czas przechowywania } \\
\text { [tygodnie] }\end{array}$} \\
\cline { 3 - 5 } & & $\mathbf{0}$ & $\mathbf{3}$ & $\mathbf{6}$ \\
\hline Rancimat & $\mathrm{h}$ & 54,5 & 56,1 & 56,1 \\
\hline PetroOXY & $\mathrm{min}$ & 116 & 99 & 106 \\
\hline Liczba nadtlenkowa & $\mathrm{meq} / \mathrm{kg}$ & 3,6 & 4,7 & 6,3 \\
\hline $\begin{array}{l}\text { Całkowita zawartość } \\
\text { zanieczyszczeń }\end{array}$ & $\mathrm{mg} / \mathrm{kg}$ & - & - & 10,2 \\
\hline
\end{tabular}

Tabela 6. Wyniki badań w czasie przechowywania oleju napędowego B10 z udziałem RME produkcji C

Table 6. Test results during storage of B10 diesel fuel with the participation of $\mathrm{RME}$ of $\mathrm{C}$ production

\begin{tabular}{|l|c|c|c|c|}
\hline \multirow{4}{*}{ Wlaściwość } & \multirow{2}{*}{ Jednostka } & \multicolumn{3}{|c|}{$\begin{array}{c}\text { Czas przechowywania } \\
\text { [tygodnie] }\end{array}$} \\
\cline { 3 - 5 } & & $\mathbf{0}$ & $\mathbf{3}$ & $\mathbf{6}$ \\
\hline \hline Rancimat & $\mathrm{h}$ & 59,6 & 70,0 & 58,7 \\
\hline PetroOXY & $\mathrm{min}$ & 128 & 107 & 106 \\
\hline Liczba nadtlenkowa & $\mathrm{meq} / \mathrm{kg}$ & $<1,0$ & 2,2 & 4,1 \\
\hline $\begin{array}{l}\text { Całkowita zawartość } \\
\text { zanieczyszczeń }\end{array}$ & $\mathrm{mg} / \mathrm{kg}$ & - & - & 17,7 \\
\hline
\end{tabular}

Olej napędowy B10 (RME-B)

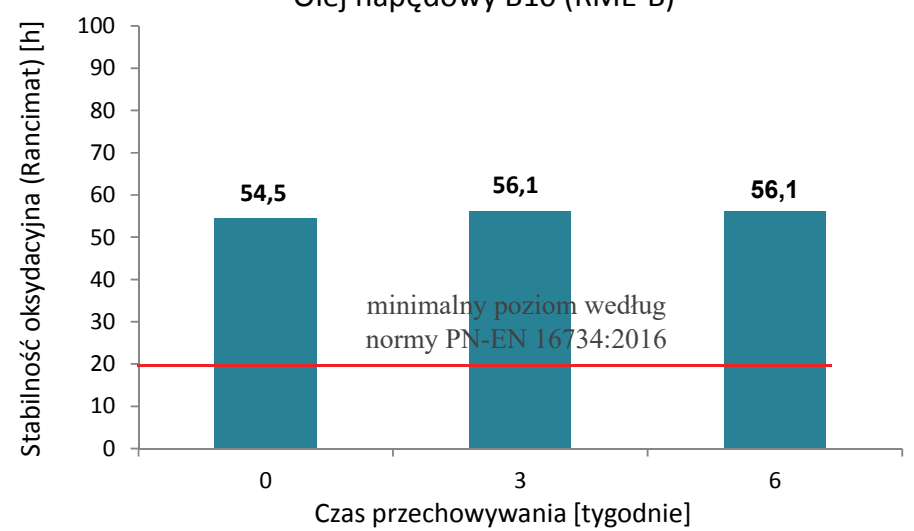

Rys. 3. Stabilność oksydacyjna (Rancimat) oleju napędowego B10 z udziałem RME produkcji B i C w czasie przechowywania

Fig. 3. Oxidation stability (Rancimat) of B10 diesel fuel with the participation of RME of B and C production during storage 

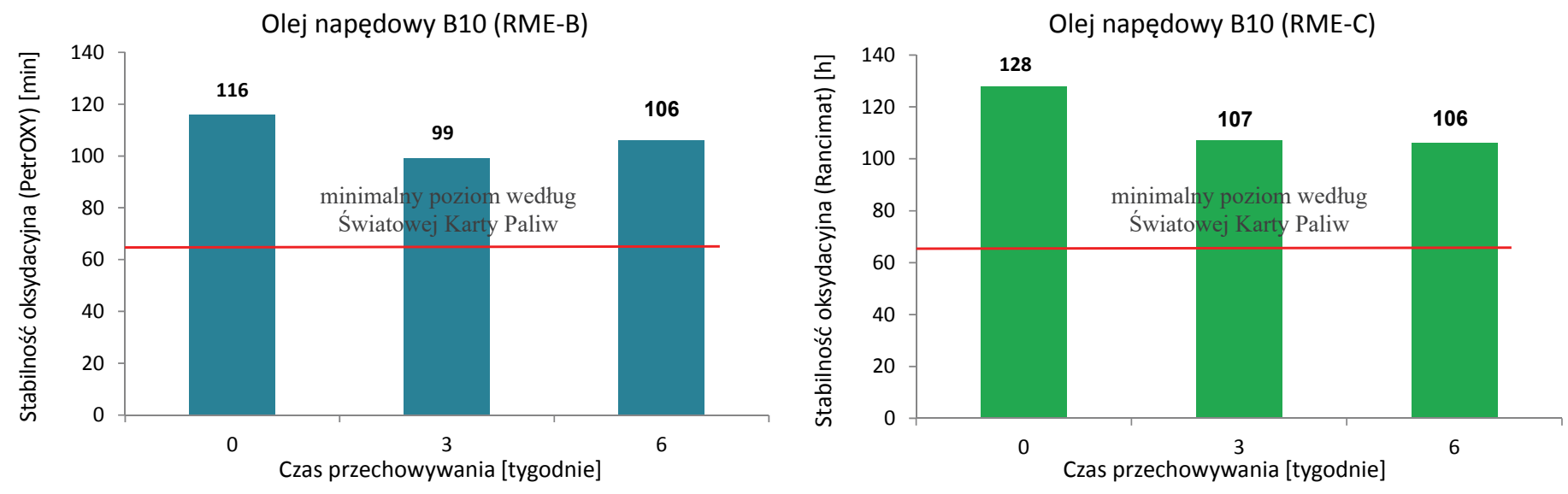

Rys. 4. Stabilność oksydacyjna (PetroOXY) oleju napędowego B10 z udziałem RME produkcji B i C w czasie przechowywania

Fig. 4. Oxidation stability (PetroOXY) of B10 diesel fuel with the participation of RME of B and C production during storage
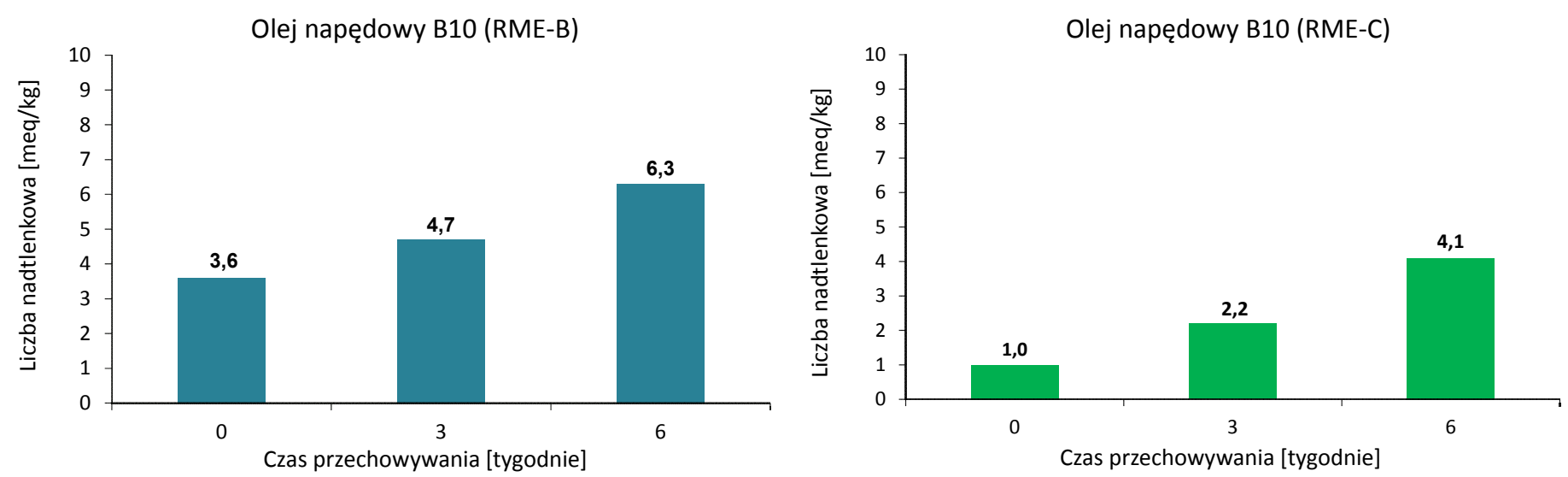

Rys. 5. Przyrost liczby nadtlenkowej oleju napędowego B10 z udziałem RME produkcji B i C

Fig. 5. Increase of the peroxide number of B10 diesel fuel with the participation of RME of $B$ and $C$ production

\section{Wnioski}

Na podstawie przeprowadzonych badań oleju napędowego zawierającego 10\% (V/V) FAME uszlachetnionego pakietem cetanowym Energocet ${ }^{\circledR}$ sformułowano następujące wnioski:

- Stwierdzono, że w okresie sześciotygodniowego przechowywania próbek oleju B10 uszlachetnionych pakietem cetanowo-detergentowym Energocet ${ }^{\circledR}$ :

- stabilność oleju B10 z udziałem RME-B według PN-EN 15751 po trzech i sześciu tygodniach przechowywania próbek wynosi odpowiednio: 56,1 h i 56,1 h;

- stabilność oleju B10 z udziałem RME-C według PN-EN 15751 po trzech i sześciu tygodniach przechowywania próbek wynosi odpowiednio: 70,0 h i 58,7 h.

- Stwierdzono, że w okresie sześciotygodniowego przechowywania próbek oleju B10 uszlachetnionych pakietem cetanowo-detergentowym Energocet ${ }^{\circledR}$ :

- stabilność oleju B10 z udziałem RME-B według PNEN 16091 po trzech i sześciu tygodniach przechowywania próbek wynosi odpowiednio: 99 min i 106 min;
- stabilność oleju B10 z udziałem RME-C według PN-EN 16091 po trzech i sześciu tygodniach przechowywania próbek wynosi odpowiednio: $107 \mathrm{~min}$ i $106 \mathrm{~min}$.

- Przebadano wpływ dodatku cetanowo-detergentowego Energocet $^{\circledR}$ w ilości $1500 \mathrm{mg} / \mathrm{kg}$ w oleju napędowym B10 z udziałem RME-B i RME-C na skłonność do generowania wolnych rodników w czasie sześciotygodniowego przechowywania próbek w temperaturze $43^{\circ} \mathrm{C}$ oznaczonych w postaci liczby nadtlenkowej według normy PN-EN ISO 3960, uzyskując następujące wyniki:

- po trzech i sześciu tygodniach przechowywania oleju B10 z udziałem RME-B odpowiednio: 4,7 meq $/ \mathrm{kg}$ i $6,3 \mathrm{meq} / \mathrm{kg}$;

- po trzech i sześciu tygodniach przechowywania oleju B10 z udziałem RME-C odpowiednio: 2,2 meq $/ \mathrm{kg}$ i $4,1 \mathrm{meq} / \mathrm{kg}$.

- Oznaczono całkowitą zawartość zanieczyszczeń dla przechowywanych próbek oleju B10 uszlachetnionego $1500 \mathrm{mg} / \mathrm{kg}$ dodatku Energocet ${ }^{\circledR}$ po sześciu tygodniach, uzyskując następujące wyniki: 
- dla oleju B10 z udziałem RME-B - 10,2 mg/kg;

- dla oleju B10 z udziałem RME-C - 17,7 mg/kg.

- Potwierdzono, że opracowany dodatek cetanowo-detergentowy Energocet ${ }^{\mathbb{B}}$, wpływający na proces szybkości spalania kinetycznego i dyfuzyjnego w silnikach o zapłonie samoczynnym, spełnia wymagania:

- stabilności oksydacyjnej oznaczonej metodami Rancimat $^{\circledR}$ i PetroOXY w czasie sześciotygodniowego przechowywania próbek oleju napędowego B10 z udziałem dodatku w ilości $1500 \mathrm{mg} / \mathrm{kg}$;

- zawartości całkowitych zanieczyszczeń poniżej $24 \mathrm{mg} / \mathrm{kg}$ po sześciotygodniowym okresie przechowywania próbek w temperaturze $43^{\circ} \mathrm{C}$, odpowiadającym 6-miesięcznemu przechowywaniu uszlachetnionych dodatkiem Energocet ${ }^{\circledR}$ w ilości $1500 \mathrm{mg} / \mathrm{kg}$ olejów B10 magazynowanych w podziemnych zbiornikach w temperaturze $21^{\circ} \mathrm{C}$.

Artykuł powstał na podstawie pracy badawczej pt. Zaawansowany technologicznie dodatek do oleju napędowego dla maszyn pozadrogowych ze szczególnym uwzględnieniem maszyn górnictwa podziemnego o znaczaco ulepszonych właściwościach energetycznych i emisyjnych - praca INiG - PIB na zlecenie NITROERG S.A.; nr zlecenia: 0429/TM/2018, nr archiwalny: DK-4100-0154/2018.

\section{Literatura}

Cataluna R., da Silva R., 2012. Effect of Cetane Fuel Consumption and Particulate Matter and Unburned Hydrocarbon Emissions from Diesel Engines. Journal of Combustion, 738940: 6. DOI: $10.1155 / 2012 / 738940$.

Dunn R.O., 2008. Effect of Temperature on the Oil Stability Index (OSI) of Biodiesel. Energy and Fuels, 22: 657-66. DOI: 10.1021/ ef700412c

Fang H.L., Stehouwer D.M., Wang. J., 2003. Interaction Between Fuel Additives and Oil Contaminant: (II) Its Impact on Fuel Stability and Filter Plugging Mechanism. SAE Technical Paper 2003-01-3140

Heywood J.B., 1988. Internal combustion engine fundamentals. McGrow-Hill, New York.

Ladommatos N., Parsi M., Knowles A., 1996. The effect of fuel cetane improver on diesel pollutant emission. Fuel, 75(1): 8-14 DOI: 10.1016/0016-2361(94)00223-1.

McCormick R.L., Westbrook S.R., 2010. Storage Stability of Biodiesel and Biodiesel Blend. Energy and Fuels, 24: 690-698. DOI: 10.1021/ef900878u.

Owen K., Coley T., Weaver C.S., 1990. Automotive Fuels Reference Book. Second edition. Society of Automotive Engineers.

Siemionow N., 1956. Chemical Kinetic and Chain Reactions. Oxford University Press.

Stanik W., 2017. Wpływ dodatku zwiększającego liczbę cetanową na właściwości zapłonowe i proces spalania oleju napędowego w silniku o zapłonie samoczynnym. Nafta-Gaz, 9: 651-659. DOI: $10.18668 / \mathrm{NG} .2017 .09 .04$.

Stanik W., Łaczek T., 2020. Analiza procesów zachodzących podczas utleniania estrów metylowych wyższych kwasów tłuszczowych (FAME) oraz oleju napędowego B10 na podstawie danych literaturowych. Nafta-Gaz, 10: 46-51. DOI:10.18668/NG.2020.10.10.
Ulmann J., Geduldig M., 2009. Effects of Fuel Impurities and Additive Interactions on the Formation of Internal Diesel Injector Deposits. $7^{\text {th }}$ International Colloquium Fuels, Technische Akademie Esslingen (TAE), Esslingen.

WWFC, 2019. Worldwide Fuel Charter, Sixth Edition.

Yannwang D., Meilini Z., Dong X., Xiaobei Ch., 2002. An analysis for effect of cetane number on exhaust emissions from engine with the neutral network. Fuel, 81(15): 1963-1970. DOI: 10.1016/ S0016-2361(02)00112-6.

\section{Normy}

ASTM D4625 Standard Test Method for Middle Distillate Fuel Storage Stability at $43^{\circ} \mathrm{C}\left(110^{\circ} \mathrm{F}\right)$.

Directive 2009/28/EC of the European Parliament and of the Counci of 23 April 2009 on the promotion of the use of energy from renewable sources and amending and subsequently repealing directives 2001/77/EC and 2003/30/EC.

Directive 2009/30/EC of the European Parliament and of the Council of 23 April 2009 amending Directive 98/70/EC as regards the specification of petrol, diesel and gas-oil and introducing a mechanism to monitor and reduce greenhouse gas emissions and amending Council Directive 1999/32/EC as regards the specification of fuel used by inland waterway vessels and repealing Directive 93/12/EEC

PN-EN 15751:2014 Paliwa do pojazdów samochodowych - Estry metylowe kwasów thuszczowych (FAME) jako samoistne paliwo i ich mieszaniny z olejem napędowym - Oznaczanie stabilności oksydacyjnej metodą przyspieszonego utleniania.

PN-EN 16091:2011 Oznaczanie stabilności oksydacyjnej metodą szybkiego utleniania w małej skali. Paliwa i mieszaniny ze średnich destylatów naftowych i estrów metylowych kwasów tłuszczowych (FAME).

PN-EN 16734:2016 Paliwa do pojazdów samochodowych. Olej napędowy B10 do pojazdów samochodowych. Wymagania i metody badań.

PN-EN 590:2017 Paliwa do pojazdów samochodowych - Oleje napędowe - Wymagania i metody badań.

PN-EN ISO 3960:2012 Oleje i tłuszcze roślinne oraz zwierzęce Oznaczanie liczby nadtlenkowej - Jodometryczne (wizualne) oznaczanie punktu końcowego.

PN-EN 14214 + A1:2014 Estry metylowe kwasów tłuszczowych (FAME) do użytku w silnikach samochodowych o zapłonie samoczynnym (Diesla) i zastosowań grzewczych. Wymagania i metody badań.

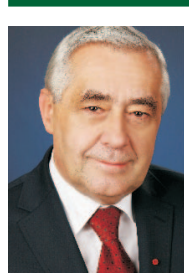

Dr Winicjusz STANIK

Adiunkt; kierownik Zakładu Produkcji

Doświadczalnej i Małotonażowej oraz Sprzedaży

Instytut Nafty i Gazu - Państwowy Instytut Badawczy

ul. Lubicz 25 A, 31-503 Kraków

E-mail: winicjusz.stanik@inig.p

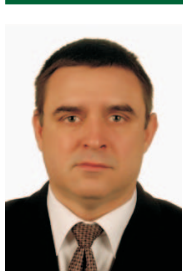

Mgr inż. Tomasz ŁACZEK

Starszy specjalista badawczo-techniczny w Zakładzie Paliw i Procesów Katalitycznych

Instytut Nafty i Gazu - Państwowy Instytut Badawczy ul. Lubicz 25 A

31-503 Kraków

E-mail:tomasz.laczek@inig.pl 